JIIP: Jurnal IImiah IImu Pemerintahan

Volume 6, Nomor 1, Tahun 2021

DOI: 10.14710/jiip.v6i1.10198

\title{
Kepemimpinan Perempuan dan Tata Kelola Tambang di Bojonegoro
}

\author{
Resya Famelasari ${ }^{1}$, Juwita Hayyuning Prastiwi ${ }^{2}$ \\ 1,2 Program Studi IImu Politik, Universitas Brawijaya
}

\begin{abstract}
INTISARI
Penelitian ini berfokus pada kajian tentang akomodasi isu gender dalam pemerintahan dan tata kelola tambang di Kabupaten Bojonegoro. Kabupaten ini dipilih sebagai lokasi penelitian dengan dua alasan, pertama bahwa sejak tahun 2018 Bojonegoro dipimpin oleh bupati perempuan dan kedua, Bojonegoro juga merupakan daerah pertambangan minyak dan gas bumi. Kepemimpinan Anna Mu'awanah di Bojonegoro menarik untuk dikaji, mengingat isu gender diangkat sebagai salah satu visi pada saat pemilihan kepala daerah berlangsung. Melalui metode penelitian kualitatif yang dipadukan dengan perspektif feminisme sebagai pisau analisis, penelitian ini memperoleh hasil antara lain bahwa transisi kepemimpinan Suyoto ke Anna Mu'awanah tidak menampakkan perubahan signifikan, terhadap transformasi kebijakan perempuan dan tata kelola tambang. Suyoto sebagai bupati laki-laki, ternyata lebih banyak menghasilkan produk kebijakan pro-perempuan dan pengendalian dampak tambang seperti peraturan daerah Dana Abadi Migas, sebaliknya Anna belum memiliki satupun peraturan daerah terkait tata Kelola tambang. Dalam konsep keterwakilan politik, kepemimpinan Anna Muawanah dapat dikategorikan sebagai kepemimpinan formalistik dan simbolik. Meskipun dalam penunjukan pimpinan dinas dan badan di lingkungan Pemerintah Bojonegoro, Anna banyak memilih perempuan, namun kebijakan Anna yang spesifik mempertimbangkan perempuan belumlah banyak. Kalaupun ada, secara kualitatif kebijakan tersebut tampak lebih memasukkan kebutuhan gender praktis dibandingkan kebutuhan gender strategis.
\end{abstract}

\section{KATA KUNCl}

keterwakilan politik; kepemimpinan perempuan; tata Kelola tambang; feminisme

\section{Pendahuluan}

Kepemimpinan perempuan di daerah, diharapkan mampu membawa perubahan tata kelola pemerintahan dan pembangunan yang berlandaskan keberpihakan pada kelompok minoritas, terutama kelompok perempuan itu sendiri. Dari sisi lingkungan, sifat-sifat perempuan seperti kepedulian, kasih sayang dan naluri perawatan dianggap sebagai sifat yang linear dengan upaya konservasi dan perlindungan alam dalam ekofeminisme. Sebagai salah satu aliran feminis, ekofeminisme memahami wujud peran perempuan dalam pelestarian lingkungan yang termanifestasi dalam bentuk gerakan

Korespodensi:

Program Studi Ilmu Politik, Fakultas Ilmu Sosial dan Ilmu Poitik, Universitas Brawijaya, Jl. Veteran, Ketawanggede, Kec. Lowokwaru, Kota Malang, Jawa Timur 65145.

Email: resyafamela@ub.ac.id 
R. Famelasari \& J. H. Prastiwi Kepemimpinan Perempuan dan Tata Kelola Tambang di Bojonegoro

perlawanan terhadap dominasi korporasi pada alam yang cenderung mengabaikan kebutuhan perempuan.

Dalam beberapa penelitian terdahulu, Lumban Gaol (2019) menganalisis tergerusnya isu feminis dalam konsolidasi demokrasi masa kini. Agenda feminism tidak berkorelasi secara langsung dengan keikutsertaan perempuan dalam politik elektoral. Seiring dengan argumentasi tersebut Atnike Nova (2019) politik keterwakilan perempuan secara substantif tidak berjalan dalam konteks organisasi perempuan dan parlemen. Pratiwi (2019) lemahnya perwakilan politik perempuan secara substatntif terjadi dalam ruang partai politik yang meskipun telah mengafirmasi kebijakan kuota $30 \%$ dalam AD/ART tetapi tidak mengadopsi ideologi pengarusutamaan gender secara program maupun keputusan parpol, dan perempuan parlemen mengalami intimidasi dan kekerasan psikis dalam mengusung agenda feminis.

Dewi (2001) Politik perempuan pada dasarnya banyak dimanivestasikan dalam bentuk Gerakan perempuan untuk melawan penindasan oleh otoritas kekuasaan yang lebih tinggi. Gerakan politik perempuan tersebut dalam Idris (2010) mewacanakan isu status pekerjaan, Pendidikan, sosioekonomi perempuan. Sedangkan apabila membahaskan tentang feminism dalam kepemimpinan menurut Nuryati (2015), terdapat kajian yang cenderung menyamakan laki-laki dan perempuan dan mengabaikan perbedaan keduanya, sedangkan beberapa kajian menyatakan gaya kepemimpinan perempuan lebih democratic sedangkan laku-laki merasa lebih sesuai dengan gaya yang directive (menekankan pada cara2 perintah)

Analisis mengenai kepemimpinan perempuan banyak difokuskan pada hambatanhambatan multidimensi yang dihadapi oleh perempuan. Misalnya pada studi Anshor (2008), ia membahas aspek sosio kultural yang memengaruhi kepemimpinan perempuan dalam konteks pengaruh Nadhlatul Ulama (NU). Di dalam studinya, Maria menyimpulkan bahwa budaya patriarki telah menjadi akar dominasi laki-laki secara luas di arena politik, termasuk dalam proses formulasi aturan serta standar permainan politik yang meminggirkan kepentingan perempuan.

Berbagai studi terdahulu, umumnya melihat kepemimpinan perempuan dalam struktur organisasi maupun institusi pemerintahan secara baik. Bahwa perempuan dinilai dapat mempertahankan karakter feminin dalam kepemimpinan, seperti lebih mengayomi bawahan. Berdasarkan penelitian terdahulu tersebut sebenarnya masih terdapat gap secara keilmuan yaitu mengenai kekhasan wujud dalam transisi kebijakan pemimpin laki-laki kepada perempuan. Mayoritas penelitian terdahulu memfokuskan penelitian mereka pada karakter kepemimpinan, tetapi tidak ada yang secara spesifik mengungkapkan transformasi kepemimpinan laki-laki menjadi kepemimpinan perempuan, terutama dalam kebijakan-kebijakan yang dihasilkan. 
Namun demikian, terlepas dari praktik nilai feminin dari pemimpin perempuan, mereka tetap kelompok minoritas yang cenderung tersubordinasi dalam proses pengambilan keputusan. Meski telah memasuki lembaga pemerintahan, tanpa kesadaran kritis serta tanpa posisi strategis, akan sulit bagi perempuan menghasilkan kebijakan yang sensitif gender. Institusi parlemen dan institusi partai politik umumnya adalah institusi yang pariarkis. Sehingga melalui pengaruh dari dua institusi ini, dapat saja pemimpin perempuan tetap mempraktikkan kebijakan yang maskulin.

Bojonegoro dipilih sebagai lokasi penelitian karena sebagai daerah kaya akan minyak dan pertambangan, daerah tersebut dipimpin oleh seorang perempuan yaitu $\mathrm{Dr}$. $\mathrm{Hj}$. Anna Muawanah. Menurut Himmah yang merupakan anggota KPI (Koalisi Perempuan Indonesia), ada beberapa persoalan atau isu perempuan di Bojonegoro, diantaranya seperti kasus kekerasan seksual, tingginya kasus perceraian, isu kesehatan perempuan, serta pernikahan dini (wawancara Himmah, 12 Juli 2020).

Secara khusus terkait dengan bidang kesehatan, berdasarkan data tahun 2018 menunjukkan adanya kekurangan energi kronis pada perempuan di Kabupaten Bojonegoro. Pada tahun tersebut, jumlah ibu hamil yang kekurangan energi mengalami peningkatan sebanyak 497 kasus dibandingkan tahun sebelumnya (Pemkab Bojonegoro, 2019a).

Tabel 1. Jumlah Ibu Hamil Kekurangan Energi serta yang mendapat zat besi:

\begin{tabular}{cccc}
\hline Tahun & $\begin{array}{c}\text { Jumlah ibu } \\
\text { hamil }\end{array}$ & $\begin{array}{c}\text { Kurang energi } \\
\text { kronis }\end{array}$ & $\begin{array}{c}\text { Mendapat zat } \\
\text { besi }\end{array}$ \\
\hline 2011 & 21165 & - & 19126 \\
\hline 2012 & 20079 & - & 19892 \\
\hline 2013 & 19794 & 1795 & 18669 \\
\hline 2014 & 19516 & 1945 & 18741 \\
\hline 2015 & 18975 & 1830 & 18047 \\
\hline 2016 & 18745 & 2167 & 16002 \\
\hline 2017 & 18527 & 2200 & 16139 \\
\hline 2018 & 18307 & 2697 & 15460 \\
\hline
\end{tabular}

Sumber: Bojonegoro Bojonegoro Dalam Angka Tahun 2019

Pada sisi lain, jumlah laki-laki dan perempuan relatif seimbang di Bojonegoro, namun demikian data Bojonegoro dalam Angka tahun 2019 memperlihatkan bahwa angka kelahiran perempuan pada wilayah Kabupaten Bojonegoro lebih sedikit dibandingkan dengan laki-laki. Pada penjabaran angka kelahiran perempuan dengan jumlah ibu hamil dan kekurangan energi kronis, bisa disimpulkkan bahwa kebertahanan hidup laki-laki di wilayah Bojonegoro lebih tinggi daripada perempuan. Apalagi angka kematian bayi pada tahun 2018 semakin meningkat sebanyak 497 kasus per tahun. Dengan demikian dalam isu kesehatan, perempuan lebih rentan dibandingkan laki-laki. 
Hal ini bisa disebabkan karena akses kesehatan yang buruk seperti fasilitas kesehatan kurang memadai dan kurangnya tenaga kesehatan (Bojonegoro, 2019).

Keterwakilan perempuan di Kabupaten Bojonegoro juga menjadi isu menarik untuk diperhatikan, terutama keterwakilan perempuan dalam DPRD. Tidak seperti periode sebelumnya, keterwakilan perempuan hasil pemilu 2019 mengalami penurunan. Total anggota DPRD perempuan saat ini hanyalah 4 (empat) orang dari 50 anggota (wawancara Mitroatin, 12 Juli 2020). Artinya, apabila di lembaga eksekutif perempuan di Bojonegoro mendapatkan posisi strategis, namun di DPRD perempuan menjadi kelompok yang underrepresented.

Bojonegoro sendiri sebagai lokasi penelitian, merupakan wilayah tambang yang telah dimulai secara tradisional sejak tahun 1870. Pada tahun 2001, Mobil Cepu Ltd yang merupakan anak perusahaan Exxon Mobil, bekerjasama dengan Pertamina mengeksplorasi minyak di wilayah Banyurip, Sukowati, Gayam dan Cepu. Sedangkan di wilayah Kedewan, setidaknya ada empat desa yang memiliki sumur tua dan masih melakukan aktivitas penambangan minyak secara tradisional yakni di Desa Hargomulyo, Beiji, Dandangilo dan Desa Wonocolo (Siddiqoh, 2015).

Namun, ramainya pemberitaan tentang tambang minyak di Bojonegoro sendiri baru dikenal luas sejak Exxon memulai aktivitas pertambangan yang dikenal sebagai blok Cepu. Keberadaan blok Migas tersebut menjadi magnet bagi masyarakat lokal hingga internasional, pasalnya Bojonegoro awalnya lebih dikenal sebagai kota jati tak lama kemudian menjadi daya tarik bagi investor yang berkompetisi memperebutkan kesempatan bisnis Migas. Ditemukannya cadangan Migas Bojonegoro yang besar, menjadi pemberitaan yang menarik bagi media, Migas berikutnya menjadi ikon baru Bojonegoro hingga dijuluki sebagai "Indonesia's texas".

Selain masalah-masalah sosial, tambang di Bojonegoro juga memunculkan permasalahan lingkungan. Misalnya bahwa perusahaan besar yang mengeksplorasi minyak diketahui terlambat menurus perizinan AMDAL. Hal ini terekam dalam pemberitaan yang menyebutkan bahwa pada tahun 2006 PetroChina terlambat mengurus AMDAL di kawasan tambang Sukowati. Selain soal perizinan, permasalahan lingkungan lain juga berkaitan dengan sumur-sumur tua yang dieksplorasi secara tradisional di Bojonegoro. Pada 25 September 2019, Dinas Lingkungan Hidup Pemprov Jawa Timur bersama Dinas Lingkungan Hidup Kabupaten Bojonegoro membahas tentang kondisi pertambangan di sumur tua Kedewan yang semakin parah. Beberapa kerusakan yang tampak meliputi pencemaran akibat limbah minyak, rusaknya hutan. Bahkan saat ini, kualitas tanah di wilayah Kedewan menurun hingga tidak dapat lagi ditumbuhi tanaman (Safuan, 2019).

Dengan berbagai persoalan lingkungan yang muncul di Bojonegoro, penelitian ini mencoba melihat bagaimana apabila perempuan mendapatkan peluang dan 
kesempatan untuk mendapatkan posisi strategis. Adakah perubahan-perubahan kebijakan serta bagaimanakah perspektif feminisme tampak dalam wujud transisi kebijakan baik dalam isu perempuan maupun isu lingkungan. Penelitian ini tidak hendak memfokuskan pada gaya atau karakter kepemimpinan, namun berupaya melihat lebih dalam mengenai wujud transisi kebijakan khususnya dalam kebijakan yang sensitif gender dan pengelolaan SDA di daerah pertambangan.

Untuk menjawab berbagai persoalan gender dan tata Kelola tambang di Bojonegoro, penelitian ini memilih menggunakan perspektif feminis serta konsep keterwakilan politik perempuan sebagai pisau analisis. Rendahnya jumlah perempuan kepala daerah berakar pada rendahnya jumlah calon kepala daerah perempuan. Rendahnya jumlah perempuan kepala daerah, menunjukkan bahwa kesulitan pencalonan perempuan dalam pilkada diakibatkan oleh tiadanya aturan yang mampu menekan partai politik, sebagaimana pada pencalonan legislatif. Maka hulu persoalan, terletak pada keengganan partai politik untuk memfasilitasi lebih banyak perempuan di dalam daftar calon kepala daerah.

Hal lain yang patut dicatat adalah, bahwa faktor keterpilihan perempuan dalam pilkada - sebagaimana diulas dalam data-data hasil riset CWI - juga sama dengan keterrpilihan mereka di parlemen, yakni cenderung disebabkan karena kedekatan perempuan dengan dinasti politik yang sedang atau pernah berkuasa di wilayah tersebut. Maka di sini, problem keterwakilan perempuan di ranah eksekutif memiliki kemiripan dengan ranah legislatif, di mana kompetisi terbatasi pada perempuanperempuan dari lingkaran kekerabatan elit.

\section{Keterwakilan Politik Perempuan dan Perspektif Ekofeminisme}

Secara ideal, kehadiran perempuan di dalam jabatan publik, diharapkan mampu menjadi katalisator bagi perubahan-perubahan yang lebih kualitatif. Terkait perubahan kualitatif ini, National Democratic Institute (NDI) dalam artikel berjudul "Why Women in Politics" menyimpulkan lima bukti empiris yang membuat kehadiran perempuan di politik sangatlah penting, antara lain: 1) Women work across party lines, 2) Women lawmakers are highly responsive to constituent concern, 3) Women help secure lasting peace, 4) Women's participation encourages citizen confidence in democracy, 5) Women priorities education, health, and other key development indicators (NDI, 2016).

Perempuan memiliki jangkauan pengalaman yang berbeda dibandingkan dengan laki-laki, maka kehadiran perempuan dalam politik diharapkan dapat mengubah praktik politik yang maskulin menjadi lebih feminin. Output dari kepemimpinan perempuan yang diharapkan diantaranya adalah lahirnya kebijakan-kebijakan dan penganggaran yang sensitif gender. Soal keterwakilan substantif ini sendiri, dapat merujuk pada pemikiran Hanna Pitkin dalam (Childs, Sarah, \& Lovenduski, 2020) yang menyebutkan 4 
(empat) tipe keterwakilan antara lain authorization atau formalistic representation, descriptif representation, symbolic representation dan substantive representation (Childs, Sarah, \& Lovenduski, 2012).

Sebagai penjelasannya, konsep authorized atau formalistic melihat hukum/legalitas dan kewenangan untuk mewakili. Melalui pendekatan ini, representasi dilihat sebagai suatu pemberian dan pemilikan, bahwa kewenangan oleh wakil sebagai individu yang diberi kewenangan untuk melakukan tindakan Sebaliknya terwakil adalah yang memberikan beberapa haknya, harus mampu bertanggungjawab atas konsekuensi tindakan yang dilakukan oleh wakil. Berikutnya konsep perwakilan descriptive, melihat "kesamaan" para wakil merefleksikan kelompok yang ada di dalam masyarakat, tetapi tidak secara inheren melakukan sesuatu untuk konstituen. Misalnya karena perempuan adalah setengah dari populasi, maka seharusnya sejumlah itu pula perempuan diwakili dalam parlemen (Childs, Sarah, \& Lovenduski, 2012).

Konsep keterwakilan symbolic melihat sisi psikologis, apakah perempuan merasa telah diwakili oleh sang wakil, termasuk bagaimana penerimaan terhadap politisi perempuan. Umumnya studi tentang keterwakilan simbolik melibatkan media massa, untuk mengukur pshycological engagement antara wakil dengan yang diwakili. Terakhir adalah konsep keterwakilan substantive melihat makna/isi dari perilaku wakil apakah sesuai masyarakat pemilihnya dan mewakili kepentingan mereka (Childs, Sarah, \& Lovenduski, 2012).

Melalui empat konsep ini, Hanna Pitkin menyediakan seperangkat alat analisis untuk melihat apakah wakil benar-benar mencerminkan kepentingan masyarakat, bahwa belum tentu wakil perempuan dapat mempraktikkan keterwakilan substantif, karena dapat saja ia terjebak dalam bentuk keterwakilan lainnya. Dalam hal ini, Ashley Judd berpendapat bahwa patriarki bukanlah laki-laki, namun patriarki adalah sistem di mana laki-laki dan perempuan turut berpartisipasi didalamnya. Pendapat ini secara practical disuarakan oleh Shiva (1997) yang dikenal sebagai tokoh ekofeminisme, dalam bukunya yang berjudul "Bebas dari Pembangunan". Shiva mengungkapkan bahwa prinsip feminitas adalah the sustenance perspectif yakni prinsip yang dibutuhkan oleh kehidupan yang berciri perdamaian, keselamatan, kasih sayang dan kebersamaan. Sedangkan maskulinitas memiliki ciri seperti persaingan, dominasi, eksploitasi dan juga penindasan. Bagi Shiva, prinsip-prinsip feminitas bukanlah privilege yang dimiliki oleh perempuan, begitupula dengan maskulinitas juga bukan ciri yang hanya dimiliki oleh laki-laki.

Pemikiran ekofeminisme sendiri, berangkat dari filosofi yang melihat situasi eksploitasi oleh alam sejalan dengan penindasan yang dialami perempuan. Sejak revolusi industri, alam mengalami eksploitasi karena menjadi sumber komoditas utama industrial negara maju dan negara berkembang. Kebergantungan ekonomi pada sektor 
komoditas alam menjadi penyebab kerusakan keseimbangan ekosistem alam yang menyebabkan krisis lingkungan .

Hakikat feminisme adalah perlawanan terhadap penindasan, dominasi, hegemoni, ketidakadilan, dan kekerasan yang terjadi terhadap perempuan. Feminisme, meskipun memiliki banyak bentuk sejak feminisme liberal pertama kali diperkenalkan, namun ontologinya adalah suatu prinsip bahwa hubungan gender antara laki-laki dan perempuan selalu diwarnai ketidakadilan dan penindasan dengan korban terdepannya adalah perempuan. Seluruh aliran feminisme sejak gelombang pertama hingga ketiga, berupaya mengidentifikasi dua hal yakni penyebab dari ketidakadilan terhadap perempuan dan mencari strategi cara mengatasi ketertindasan tersebut, hal inilah yang membedakan antara satu aliran feminisme dengan aliran feminisme lainnya .

Di dalam ekofeminisme sendiri, melihat bahwa subordinasi yang diberikan pada perempuan di negara berkembang sama dengan pengabaian terhadap alam. Vandana Shifa seorang fisikawan yang berasal dari India merupakan seorang filsuf ekofeminisme yang memandang perempuan dalam sistem patriarki, merupakan korban dari manusia yang hidup dalam bias kapitalis. Namun sekali lagi, penekanan Shiva adalah tidak melihat perempuan secara sempit sebagai kategori sosial, namun perempuan muncul karena diangkat dari realitas konkrit yang terjadi di negara dunia ketiga terutama India (Shiva, V., \& Mies, 2005).

Vandana shifa menggunakan kondisi nyata yang terjadi di India yang memiliki hubungan yang begitu dekat dengan alam yaitu dalam sebuah tragedi yang ironis dialami oleh perempuan India dalam Gerakan Chipko, yakni suatu gerakan yang berupaya mempertahankan hutan dari cengkeraman industri kapitalis. Peradaban yang dipengaruhi sistem kapitalisme memunculkan mentalitas untuk berkuasa, hal ini menjadi ciri khas penaklukan alam demi kepentingan manusia merupakan peradaban masyarakat patriarki. Manusia dalam peradaban ini adalah manusia patriarkis yang memandang alam dan perempuan merupakan objek bagi mereka yang berkuasa. Bahkan pada saat alam dieksploitasi, keuntungan yang didapatkan manusia patriarkal tidak diberikan kepada perempuan maupun keluarganya dan keuntungan lebih cenderung untuk memenuhi kepuasan dirinya sendiri (Zega, Christiani \& Saraswati, 2014).

Meskipun persepektif ekofeminisme tidak mengidentifikasikan perempuan secara sempit dipahami sebagai jenis kelamin tetapi konsep perempuan dalam realitas masyarakat lokal di negara dunia ketiga menjadi unsur utama yang diidentifikasi memiliki kepedulian dan caring sense terhadap alam. Perspektif tersebut digunakan menjadi landasan untuk meletakkan fokus dari penelitian ini bahwa perempuan di negara dunia ketiga yang dapat menghadirkan perubahan melalui kedekatan dengan 
alam yang diharapkan mampu melahirkan transisi dan perubahan pada cara pandang pembangunan yang konvensional (Zega, Christiani \& Saraswati, 2014).

Penelitian ini menggunakan desain metode kualitatif, selain dimaksudkan untuk mendapat gambaran utuh atas fenomena juga karena penelitian ini membutuhkan pendekatan tertentu yang sadar dan peka gender. Pendekatan sadar dan peka gender sendiri dapat diperoleh karena peneliti alam penelitian kualitatif, menjadi instrumen di dalam penelitian itu sendiri. Trisakti Handayani dalam buku "Konsep dan Teknik Penelitian Gender" menyebutkan bahwa penelitian yang berperspektif perempuan secara eksplisit memang menyatakan keberpihakannya, yaitu berfokus pada masalah perempuan di mana aspek perasaan dan pengalaman perempuan dilibatkan, kemudian mencari strategi untuk merubah keadaan yang tidak menguntungkan perempuan (Adair, 2008: 66-78; Shiva, V., \& Mies, 2005).

Proses pengumpulan data pada penelitian ini dilakukan dengan teknik wawancara mendalam, kepada informan-informan yang ditentukan dengan mekanisme purposive. Maksud dari mengadakan wawancara adalah untuk mengkonstruksikan mengenai orang, kejadian, perasaan dan motivasi terkait keadaan yang sedang dialami ataupun keadaan yang akan datang untuk kemudian dibulatkan dalam sebuah informasi. Adapun selama penelitian lapangan, jumlah informan yang berhasil diwawancara adalah sebanyak 10 orang yang berasal dari perwakilan Pemerintah Bojonegoro, partai politik dan civil society organizations.

\section{Kepemimpinan Perempuan dan Transisi Kebijakan Pro-Perempuan}

Menguatnya dukungan terhadap kehadiran perempuan dalam proses pengambilan keputusan di Indonesia sendiri, hadir terutama pasca runtuhnya Orde Baru. Diawali kebijakan afirmasi berupa kuota minimal 30 persen, sejak tahun 2004 kebijakan tersebut dipraktikkan dalam Pemilu legislatif. Sayangnya dalam konteks Pemilihan Umum Kepala Daerah (Pilkada), kita masih belum memiliki payung hukum yang mengafirmasi pencalonan perempuan. Sejak Pilkada langsung diselenggarakan pada tahun 2005, belum ada regulasi Pilkada yang mendukung affirmative action bagi perempuan sebagaimana diamanatkan untuk Pemilu Legislatif, Hal inilah yang menyebabkan keterlibatan perempuan, rata-rata sangat kecil dalam kepemimpinan daerah di Indonesia.

Meski tanpa kebijakan afirmasi dalam Pilkada, Anna Muawanah berhasil menjadi Bupati perempuan pertama sejak Pilkada langsung diselenggarakan di Kabupaten Bojonegoro. Berpasangan dengan Budi Irawanto, Anna diusung tiga partai politik yaitu Partai Kebangkitan Bangsa (PKB), Partai Demokrasi Indonesia Perjuangan (PDIPerjuangan) dan Partai Kesatuan Pembangunan Indonesia (PKPI). Dalam Pilkada tahun 2018, pasangan Anna - Irawanto berhasil mendapatkan 236.358 suara. Dibandingkan 
dengan pasangan Soehadi - Mitroatin, pasangan Anna Irawanto hanya unggul sebesar 40.869 suara (Asyari, 2018).

Berlatar belakang pendidikan ekonomi dan manajemen bisnis, Anna Muawanah pernah menjabat sebagai anggota DPR-RI selama tiga periode yakni periode 2004-2009, periode 2009-2014 dan periode 2014-2019. Pada periode keduanya di DPR-RI, Anna bahkan sempat menjabat sebagai salah satu Ketua DPP PKB (2008 - 2013), sebagai Wakil Ketua Komisi IV selain juga menjadi delegasi PKB dalam Panitia Khusus (Pansus) Bailout Century. Maka dalam dunia politik, Anna bukanlah kader karbitan karena ia telah melalui proses politik yang cukup panjang hingga akhirnya terpilih menjadi Bupati Kabupaten Bojonegoro untuk periode 2018 - 2023 (Merdeka, 2018).

Tidak hanya di dunia politik, Anna juga terlibat dalam aktivitas-aktivitas dalam organisasi kemasyarakatan Nahdlatul Ulama (NU) sejak muda. Setelah menjabat sebagai Bupati Bojonegoro, saat ini Anna juga menjabat sebagai ketua Muslimat NU Kabupaten Bojonegoro. Hal ini berarti, secara sosio-kultural Anna memiliki pendukung kuat dari kelompok Islam tradisional NU. Sedangkan dari sisi keluarga, selama masa kampanye Anna Muawanah tampak menekankan bahwa ia merupakan keturunan Mbah Hasyim yang dikenal sebagai salah satu penyebar Islam di Bojonegoro.

Dalam hal ini, Gidden mengkontruksi identitas diri sebagai multiple identity yang melibatkan pemahaman dasar atas tingginya etos "kepemenuhan/pemenuhan diri" (self fulfillment) serta "aktualisasi diri" (self actualisation). Bagi Gidden, self tidak hanya menjadi penentuan tradisi komunitas lokal, lebih dari itu identitas diri menjadi proyek yang refleksif. Anna membuktikan itu melalui dirinya sebagai kandidat calon kepala daerah yang memiliki latar belakang sebagai seorang legislator dan pemimpin muslimat $\mathrm{NU}$, melalui data tersebut Anna memiliki unsur penting dalam kepemimpinannya, termasuk dalam proses Pilkada. Dari empat calon bupati yang ada, Anna - Irawanto berangkat dengan merepresentasikan aliran agamis dan nasionalis, sehingga selain sosok kandidat yang berpengaruh tradisi ulama atau kyai juga menjadi sokongan bagi pasangan ini.

Berkaitan dengan analisis keterwakilan perempuan yang lebih substansial, profil yang dilansir oleh Merdeka.com menyebutkan sebagai berikut :

\footnotetext{
"Ketika Anna melihat beban penderitaan yang di pikul wanita di kampung-kampung nelayan serta di pelosok-pelosok desa Tuban yang tandus, diakibatkan dari dua peran yang harus di jalani mereka sebagai ibu rumah tangga sekaligus membantu mencukupi kebutuhan hidup keluarga. Anna merasa ingin menolong kaum wanita dan Anna memutuskan untuk bergabung dengan Partai Kebangkitan Bangsa. Dia merasa terpanggil untuk menolong kaum perempuan tidak hanya dengan memberi pekerjaan. Menurutnya, butuh langkah yang lebih besar yaitu advokasi kebijakan untuk mengentaskan kaum perempuan dari jeratan kemiskinan struktural yang menimpa mereka".
} 
R. Famelasari \& J. H. Prastiwi Kepemimpinan Perempuan dan Tata Kelola Tambang di Bojonegoro

Berdasarkan kutipan profil tersebut, menampakkan adanya pemahaman serta keberpihakan terhadap kelompok perempuan, namun pertanyaannya bagaimanakah operasionalisasi atau praktik riil dari keberpihakan tersebut. Cara yang dapat ditempuh untuk melihat praktik riil dari keperpihakan terhadap perempuan adalah melalui produk kebijakan termasuk melalui berbagai dokumen pembangunan dan anggaran.

Dalam proses pencalonan sebagai pasangan calon bupati, Anna dan Irawanto berangkat dengan visi "Menjadikan Bojonegoro sebagai Sumber Ekonomi Kerakyatan dan Sosial Budaya Lokal untuk Terwujudnya Masyarakat yang Beriman, Sejahtera, dan Berdaya Saing". Visi ini sendiri, pada dasarnya tidak secara tersurat merepresentasikan kepentingan perempuan. Namun dari empat misi yang diturunkan dari visi tersebut, salah satu visi yakni visi ke-4 menyebutkan "Mewujudkan rasa aman dan keberpihakan bagi perempuan, anak, penyandang disabilitas, serta kaum dhuafa". Dengan demikian, maka kelompok minoritas seperti perempuan, anak, kelompok disabilitas dan dhuafa telah menjadi salah satu fokus untuk lima tahun kepemimpinan Anna - Irawanto.

Sebagai bupati terpilih, Anna Muawanah resmi mengemban amanah untuk periode 2018-2023. Selama kepemimpinannya hingga penelitian ini dilaksanakan, representasi dan karakteristik program kerja Anna sebagai seorang pemimpin perempuan memiliki gaya yang cenderung mengutamakan pembangunan dan ekonomi masyarakat. Padahal, pembangunan yang bersandar pada modernisasi merupakan musuh dari gerakan perempuan itu sendiri.

Beberapa kebijakan prioritas yang mucul antara lain adalah pembangunan infrastruktur jalan, pembuatan Satuan Tugas Perlindungan Perempuan dan Anak (Satgas PPA), pembuatan program Kartu Petani Mandiri (KPM) hingga kebijakan pada bidang pendidikan yaitu pemberian beasiswa dua sarjana satu desa. Selain pembentukan Satgas PPA, Anna memiliki program kerja lain yang spesifik ditujukan kepada perempuan, yakni menjadikan perempuan sebagai modén untuk penanganan jenazah perempuan, untuk setiap desa di Kabupaten Bojonegoro.

Dengan demikian, setelah mengemban amanah sebagai bupati tampak ada beberapa kebijakan pro perempuan selama kepemimpinannya. Dua kebijakan Anna yang spesifik menyebutkan perempuan tampak lebih memasukkan kebutuhan gender praktis dibandingkan kebutuhan gender strategis. Misalnya dalam pembentukan Satgas PPA, apabila kehadiran Satgas ini hanya berfokus pada tindakan kuratif dan rehabilitatif, tanpa serius berfokus pada tindakan promotif dan preventif maka angka Kekerasan Terhadap Perempuan (KTP) dan Kekerasan Terhadap Anak (KTA) akan sulit untuk ditekan signifikan. Pembentukan Satgas PPA ini sendiri bukannya tanpa kritik, politik balas budi ditengarani mendasari pembentukan Satgas PPA oleh pasangan Anna Irawanto. Satgas PPA di Bojonegoro dikuasai kelompok Fatayat dan Muslimat, hal ini ditengarai sebagai bentuk terima kasih Anna terhadap organisasi yang menaunginya. 
Diskursus kepemimpinan perempuan dalam pembangunan, tak luput karena visi yang berfokus pada ekonomi. Dominasi pola pikir yang kemudian dilegitimasi dalam kebijakan publik, menjadikan pembangunan berpotensi memarginalkan perempuan. Penekanan ke arah progress, ditandai modernisasi melalui industrialisasi sebagai motor utama penggerak pembangunan. Dalam jangka panjang, praktik ini akan memunculkan dampak yang berbeda di antara kelompok-kelompok masyarakat termasuk kelompok perempuan.

Dalam kaitannya dengan perempuan, meski memiliki dua program yang menyasar perempuan namun hasil kepemimpinan Anna sejak tahun 2018 menunjukkan bahwa Pengarusutamaan Gender (PUG) belum sepenuhnya menjadi prioritas pembangunan. Hal ini, salah satunya tampak pada masih tingginya Angka Kematian Ibu (AKI), Angka Kematian Bayi (AKB) dan Angka Kematian Balita (Akaba). Pada tahun 2018 jumlah AKB di Bojonegoro adalah sebesar 168 kasus atau 9,78 per 1000 kelahiran hidup. Dengan jumlah kematian bayi laki-laki sebanyak 95 kasus $(58,44 \%)$ dan bayi perempuan sebanyak 73 kasus (41,56\%). Jumlah AKB tahun 2018 ini mengalami peningkatan dibandingkan dengan tahun 2017 lalu dengan jumlah kasus 8,76 per 1000 kelahiran hidup. Pada data tentang Akaba di Bojonegoro, juga cenderung mengalami kenaikan, pada data tahun 2018, Akaba dilaporkan 179 kasus atau 10,42 per 1000 kelahiran hidup, sedangkan pada 2017 sebesar 9,56 per 1.000 kelahiran hidup (Dinas Kesehatan Jatim, 2018).

Data AKI di Bojonegoro juga tidak menggembirakan, hal ini karena rata-rata angka AKI masih di atas 100 tiap 100.000 kelahiran. Pada tahun 2018, AKI Bojonegoro mencapai 162,23 per 100.000 kelahiran, sedangkan pada tahun 2019 AKI Bojonegoro mencapai 149,66 per 100.000 kelahiran. Sayangnya tren penurunan AKI belum dapat disimpulkan karena sampai penelitian ini dilangsungkan jumlah AKI tahun 2020 belum ada (Dinas Kesehatan Jatim, 2018).

Tingginya AKI, AKB dan Akaba salah satunya dapat disebabkan karena aksesibilitas dan kualitas infrastruktur kesehatan yang kurang memadai. Sehingga perlu adanya cara khusus dalam menanggulangi AKI dan AKB di Bojonegoro. Seperti dengan penambahan jumlah puskesmas atau layanan kesehatan lainnya pada wilayah yang belum memiliki akses kesehatan yang baik. Fokus kepemimpinan Anna dalam hal ini, sangat diperlukan guna memberikan manfaat yang baik bagi perempuan dan anak.

Dari data tersebut, penanganan permasalahan perempuan yang mendesak memang belum menjadi prioritas utama. Sebagai seorang pemimpin perempuan, Anna belum tampak mempertimbangkan adanya kebutuhan kesehatan dan reproduksi. Selain itu, dalam dua tahun kepemimpinannya praktik nepotisme juga terekam di berbagai media. Nepotisme selama masa kepemimpinan Anna mencuat ketika menjelang pertengahan 2019, ia dan suami dituduh menggunakan dana APBD untuk perjalanan ke 
R. Famelasari \& J. H. Prastiwi Kepemimpinan Perempuan dan Tata Kelola Tambang di Bojonegoro

Inggris. Dalam berbagai pemberitaan, menyebutkan bahwa suami Anna atas nama Ali Duppa ternyata merupakan Wakil Ketua Dewan Riset Daerah (DRD) Kabupaten Bojonegoro.

Pada aspek produk legislasi, yang perlu dicatat adalah bahwa produk legislasi sebenarnya bukan semata wilayah kewenangan eksekutif di daerah, namun juga wilayah kewenangan legislatif. Dalam masa kepemimpinan Anna Muawanah, Eksekutif dan legislatif (DPRD) tampak tidak banyak menghasilkan Peraturan Daerah (Perda), termasuk Perda yang secara spesifik diujukan untuk melindungi perempuan atau lingkungan. Pada tahun 2018 tercatat ada tujuh Perda, tahun 2019 ada lima Perda dan pada tahun 2020 ada enam Perda, di antara seluruh Perda tersebut tidak satupun merujuk pada perlindungan kelompok perempuan. Berikut adalah rincian Perda Kabupaten Bojonegoro selama tiga tahun terakhir:

Tabel 2. Daftar Perda Kabupaten Bojonegoro Tahun 2018, 2019 dan 2020

\begin{tabular}{|c|c|c|c|}
\hline No & 2018 & 2019 & 2020 \\
\hline 1 & $\begin{array}{c}\text { Perda } 1 / 2018 \text { Tentang } \\
\text { Penyidik PNS }\end{array}$ & $\begin{array}{c}\text { Perda } 2 / 2019 \text { Tentang } \\
\text { RPJMD }\end{array}$ & $\begin{array}{c}\text { Perda } 1 / 2020 \text { Tentang } \\
\text { Pelestarian Kesenian } \\
\text { Tradisional }\end{array}$ \\
\hline 2 & $\begin{array}{l}\text { Perda 2/2018 Tentang } \\
\text { Penanaman Modal }\end{array}$ & $\begin{array}{l}\text { Perda 3/2019 Tentang } \\
\text { APBD tahun } 2020\end{array}$ & $\begin{array}{l}\text { Perda } 2 / 2020 \text { Tentang } \\
\text { Pengembangan dan } \\
\text { Perlindungan Koperasi } \\
\text { dan Usaha Mikro }\end{array}$ \\
\hline 3 & $\begin{array}{c}\text { Perda 3/2018 Tentang } \\
\text { Retribusi Pelayanan } \\
\text { Kesehatan RSUD }\end{array}$ & $\begin{array}{l}\text { Perda 4/2019 Tentang } \\
\text { Pertanggung Jawaban } \\
\text { Pelaksanaan APBD } 2018\end{array}$ & $\begin{array}{c}\text { Perda 3/2020 Tentang } \\
\text { Pencabutan Perda } \\
\text { 25/2011 tentang } \\
\text { Pendaftaran WP }\end{array}$ \\
\hline 4 & $\begin{array}{l}\text { Perda 4/2018 Tentang } \\
\text { Pembubaran PD Pasar }\end{array}$ & $\begin{array}{l}\text { Perda 5/2019 Perubahan } \\
\text { atas Perda No } 1 / 2017 \\
\text { tentang Perangkat Desa }\end{array}$ & $\begin{array}{c}\text { Perda 4/2020 Tentang } \\
\text { Rencana Induk } \\
\text { Pembangunan } \\
\text { Kepariwisataan }\end{array}$ \\
\hline 5 & $\begin{array}{c}\text { Perda 5/2018 Tentang } \\
\text { Pertanggungjawaban } \\
\text { Pelaksanaan APBD } \\
2017 \\
\end{array}$ & $\begin{array}{l}\text { Perda 6/2019 Perubahan } \\
\text { APBD Tahun } 2019\end{array}$ & $\begin{array}{c}\text { Perda 5/2020 Tentang } \\
\text { Perubahan atas Perda } \\
\text { 13/2016 Tentang } \\
\text { Pembentukan SKPD } \\
\end{array}$ \\
\hline 6 & $\begin{array}{l}\text { Perda 6/2018 Tentang } \\
\text { Perubahan APBD } 2018\end{array}$ & & $\begin{array}{c}\text { Perda 6/2020 Tentang } \\
\text { Pertanggungjawaban } \\
\text { APBD } 2019 \\
\end{array}$ \\
\hline 7 & $\begin{array}{c}\text { Perda 7/2018 Tentang } \\
\text { APBD } 2019\end{array}$ & & \\
\hline
\end{tabular}

Sumber: Diolah peneliti tahun 2020 
Sedangkan dalam daftar Peraturan Bupati (Perbup), tercatat bahwa pada tahun 2018 Bupati mengeluarkan 51 Perbup. Dari sejumlah 51 Perbup tersebut, hanya satu Perbup yang mengatur penanganan anak jalanan yakni Perbup No. 35 Tahun 2018. Adapun data Perbup 2019 dan 2020 tidak ditemukan yang mengakomodir perempuan, anak dan lingkungan. Sebagai catatannya, pada list Perda dan Perbup tahun 2018 dapat saja sebagian merupakan peraturan yang disahkan oleh pemerintahan sebelumnya, karena merupakan tahun transisi Kepala Daerah di Bojonegoro.

Berdasarkan data pada tabel 2 dan data Perbup, menampakkan tidak ada satupun Perda yang mengatur perlindungan perempuan ataupun yang mengatur tentang pengelolaan tambang di Bojonegoro dan perlindungan lingkungan. Perbedaan kebijakan yang dihasilkan antara Anna dan Suyoto dalam rentang waktu satu tahun, minimal Suyoto pernah mengeluarkan kebijakannya terkait perempuan atau lingkungan sebanyak satu peraturan bupati, sedangkan Anna sama sekali tidak mengeluarkan peraturan terkait perempuan ataupun lingkungan, sebaliknya Anna menghapus peraturan terkait kesehatan, hal ini merujuk pada Perbup No. 4 Tahun 2019 Tentang Pencabutan Perbup No. 18 Tahun 2014 Tentang Pedoman Pelaksanaan Pelayanan Kesehatan Pada Daerah Sulit Dijangkau (Terisolir). Tidak adanya produk politik yang berupaya melindungi kelompok perempuan, pada sisi lain dapat juga disumbang karena minimnya jumlah anggota legislatif perempuan.

Dari sisi anggaran, Bojonegoro merupakan salah satu daerah penghasil minyak bumi dan gas (Migas) yang cukup besar di Indonesia. Di sisi lain, melalui beban anggaran yang besar dari pajak Sumber Daya Alam, Bojonegoro sejak tahun 2017 hingga 2020 tidak bergeser dari posisi ke-10 Kabupaten Termiskin di Provinsi Jawa Timur (BPS, 2019). Padahal kemiskinan ini yang akan menyebabkan perempuan dan anak-anak menjadi korbannya, sebab ancaman kemiskinan ini akan mempersulit ruang dan gerak perempuan dalam kehidupan sehari-hari. Akibatnya terjadi permasalahan sosial pada perempuan diantaranya kasus kekerasan seksual, tingginya kasus perceraian, isu kesehatan perempuan, akses pendidikan dan pernikahan dini.

Dengan total anggaran belanja Rp. 4.084.708.188.953,20 untuk tahun 2020 (Pemkab Bojonegoro, 2020), kondisi kemiskinan di Bojonegoro belum juga terlewati dengan baik, karena fokus pengeluaran anggaran ada pada belanja tidak langsung yang terdiri dari belanja pegawai, belanja subsidi, belanja hibah, bantuan sosial, belanja bagi hasil, serta bantuan keuangan. Belanja terbesar pada biaya belanja tidak langsung ini berfokus pada belanja pegawai senilai Rp. 2.218.647.317.430,00, sedangkan nilai belanja subsidi untuk masyarakat hanya Rp. 223.000.000,00 (Pemkab Bojonegoro, 2020). Terlihat bahwa antara belanja untuk masyarakat dan pegawai, terpaut selisih yang begitu jauh. 
R. Famelasari \& J. H. Prastiwi Kepemimpinan Perempuan dan Tata Kelola Tambang di Bojonegoro

Meski di tingkatan produk kebijakan dan anggaran tidak terlalu menggembirakan, dalam aspek struktur pemerintah kepemimpinan Anna menunjukkan upaya-upaya mempromosikan perempuan. Dari 31 Dinas dan Badan di Kabupaten Bojonegoro, saat ini tercatat ada sembilan Dinas/Badan (atau setara 29 Persen) yang dipimpin oleh perempuan. Dinas-dinas tersebut antara lain adalah Sekretaris Daerah, Dinas Kesehatan, Badan Penanggulangan Bencana Daerah (BPBD), Dinas Pertanian, Dinas PU Bina Marga dan Penataan Ruang, Dinas Ketahanan Pangan, Dinas Pemberdayaan Perempuan dan Keluarga Berencana, Dinas Penanaman Modal, Badan Pengelolaan Uang dan Aset Daerah.

Dalam tataran pemerintahan, pemilihan Kepala Dinas memang merupakan hak prerogratif dari Bupati, dalam konteks kepemimpinan Anna maka perempuan relatif terakomodir di dalam struktur pemerintah Kabupaten. Kemudian, bagaimana dengan gaya kepemimpinan Anna dengan masyarakat Bojonegoro. Seperti diketahui bahwa selama dua periode kepemimpinan bupati sebelumnya - Bupati Suyoto -, ia banyak dipuji karena praktik keterbukaan informasi termasuk dibukanya komunikasi dua arah antara warga dengan Pemerintah Kabupaten.

Dibandingkan dengan bupati sebelumnya yaitu Suyoto, gaya/pola kepemimpinan Anna lebih cenderung tertutup. Keterbukaan informasi menjadi keunggulan semasa Bupati Suyoto, kini tidak dipraktikkan oleh Anna. Pada 15 februari 2020, suarabanyuurip.com melansir berita tentang evaluasi kepemimpinan Anna, di mana Transparency International Indonesia (TII) menyarankan kepada Pemerintah Kabupaten Bojonegoro agar menerapkan Peraturan Bupati No. 1 Tahun 2017 Tentang Keterbukaan Dokumen Kontrak. Hingga saat ini regulasi tersebut sebenarnya masih berlaku, namun TII melihat adanya kemunduran dari implementasinya, di mana keterbukaan pemerintah, keterbukaan kontrak, dan aturan lainnya tidak lagi tampak (Nugroho, 2020).

Kontestasi politik perempuan sebenarnya ada pada kualitas dirinya, sayangnya perempuan belum tentu mampu memaknai dirinya sebagai cerminan kepentingan pada komunitas pengusungnya. Kebijakan yang mengarah kepada pembangunan infrastruktur dan ekonomi, mengakibatkan kelompok perempuan berpotensi semakin termarginalkan. Adanya kesempatan bagi perempuan untuk memasuki politik justru menjadi hambatan baru bagi pemimpin perempuan, hal ini disebabkan karena mereka masih terjebak dalam kepentingan partai politik. Sayangnya, dari sisi partai politik Anna juga tidak terlalu memiliki kekuasaan. Maka di sini, Anna Muawanah tampak terjebak sebagai simbolisasi pemimpin perempuan tanpa praktik keterwakilan substantif yang memadai. 


\section{Kepemimpinan Perempuan dan Tata Kelola Tambang}

Kabupaten Bojonegoro saat ini dikenal sebagai "texas" Indonesia, istilah ini merujuk situasi bahwa di Bojonegoro terjadi pemanasan yang lebih tinggi dibandingkan dengan daerah lain. Pemanasan tersebut dipicu masifnya eksploitasi Migas. Perubahan suhu yang semakin memanas terjadi dibeberapa wilayah Bojonegoro, dengan suhu yang dapat mencapai 40 derajat celcius, berikut ini pernyataan Dedi selaku perwakilan Alianji Jurnalis Independen (AJ) Bojonegoro :

\footnotetext{
"Tidak bisa dipungkiri bahwa lokasi-lokasi tambang minyak juga memakan tempat, terutama di daerah Banyu Urip belum mencukupi ruang terbuka hijaunya. Ada lagi persoalan dua tahun ini, di bengawan solo soal pencemaran air yang hitam kemerahmerahan. Pencemaran itu dihasilkan dari jawa tengah soal batik, ada juga di Wonocolo Bojonegoro, mereka membuang bekas minyak mentah disungai. Artinya tidak ada pengelolaan limbah yang bagus...."
}

Jika eksploitasi dilakukan terus-menerus tanpa adanya tekanan kebijakan yang memadai, dampak yang lebih besar akan terjadi seperti permasalahan air, polusi, hingga dampak yang berujung pada hilangnya nyawa. Melihat fenomena pemanasan di Bojonegoro, perempuan akan menjadi salah satu dampak akibat adanya eksplotasi Migas yang berlebih. Melihat adanya permasalahan-permasalahan sosial baik yang potensial maupun aktual, kebijakan terkait tata kelola tambang yang mengukur dampak lingkungan memang perlu diperhatikan.

Tambang-tambang Migas yang beroperasi di Bojonegoro antara lain adalah Blok Cepu Lapangan Banyu Urip dan Lapangan Kedung Keris yang dikelola ExxonMobil melalui anak perusahaan ExxonMobil Cepu Ltd, Lapangan Kawengan yang dikelola oleh Pertamina Field Cepu Asset IV, kemudian Blok Tuban Lapangan Sukowati yang dikelola oleh Pertamina Asset IV. Jumlah ini masih belum termasuk tambang-tambang tradisional seperti di wilayah Kedewan (P Bojonegoro, 2014).

Berdasarkan data yang dilansir bojonegorokab.go.id, lokasi tambang Bojonegoro masih akan bertambah mengingat Blok Cepu Lapangan Jambaran-Tiung Biru saat ini sudah dalam tahap konstruksi. Selain itu, saat ini Blok Blora dengan wilayah kerja kecamatan Ngraho dan Margomulyo serta Blok Nona dengan wilayah kerja Bojonegoro Bagian Tenggara juga sudah memasuki tahap eksplorasi. Pemerintah Kabupaten Bojonegoro sendiri memperkirakan, bahwa 25 persen cadangan minyak Indonesia berada di Bojonegoro.

Dalam UU No. 22 tahun 2001 Tentang Minyak Bumi dan Gas pasal 4 ayat 2, disebutkan bahwa penguasaan minyak bumi dan gas dikuasai oleh Negara yang diselenggarakan oleh pemerintah dalam hal ini negara dan kementerian sebagai pemegang kuasa pertambangan. Dengan demikian, proses eksplorasi dan eksploitasi diserahkan kepada pemerintah pusat, sehingga peran daerah sebatas menjadi 
R. Famelasari \& J. H. Prastiwi Kepemimpinan Perempuan dan Tata Kelola Tambang di Bojonegoro

penyelenggara perizinan, bahkan sebagai bupati, IUP (Izin Usaha Pertambangan) terbatas hanya untuk memberikan rekomendasi. Di Bojonegoro sendiri, adanya perizinan tambang memberikan dampak yang signifikan terhadap pembangunan daerah diantaranya seperti meningkatkan pendapatan daerah, penggerak pembangunan daerah dan membuka lapangan pekerjaan untuk masyarakat sekitar.

Berdasarkan aturan pemerintah pusat, maka pemerintah daerah memiliki kewenangan-kewenangan tertentu dalam proses eksplorasi dan eksploitasi Migas yang ada daerah selain juga mendapatkan keuntungan-keuntungan. Saat ini di Bojonegoro, pengaturan tambang Migas masih mengacu pada Peraturan Bupati No. 48 Tahun 2011 tentang optimalisasi kandungan lokal dalam kegiatan industri Migas di Bojonegoro. Sebelum kepemimpinan Anna, Suyoto terlebih dahulu menjabat selama dua periode. Adapun beberapa perbedaan peraturan yang disahkan oleh Anna sebagai pemimpin perempuan dan Suyoto sebagai pemimpin laki-laki adalah sebagai berikut :

Tabel 3. Peraturan Bupati Tentang Tambang

\begin{tabular}{|l|l|}
\hline No & \multicolumn{1}{|c|}{ Peraturan Bupati } \\
\hline 1 & $\begin{array}{l}\text { Peraturan Bupati Bojonegoro No. 24 Tahun 2014 Tentang } \\
\text { Pelaksanaan Urusan Energi dan Sumber Daya Mineral } \\
\text { Pemerintah Kabupaten Bojonegoro Tahun Anggaran 2014 }\end{array}$ \\
\hline 2 & $\begin{array}{l}\text { Peraturan Bupati Bojonegoro No. 30 Tahun 2016 Tentang } \\
\text { Pedoman Penerbitan Rekomendasi Teknis Pengajuan Wilayah } \\
\text { Izin Usaha Pertambangan Di Kabupaten Bojonegoro. }\end{array}$ \\
\hline 3 & $\begin{array}{l}\text { Peraturan Bupati Bojonegoro No. 39 Tahun 2017 Tentang } \\
\text { Pedoman Pembinaan Kelompok Penambang Dan Penambang } \\
\text { Pada Sumur Minyak Tua Di Kabupaten Bojonegoro. }\end{array}$ \\
\hline
\end{tabular}

Sumber: Diolah oleh peneliti tahun 2020

Dalam kepemimpinan Bupati Suyoto, Pemerintah Bojonegoro merumuskan Dana Abadi Migas pada tahun 2014, yakni kebijakan yang bertujuan untuk memastikan adanya dana cadangan/tabungan bagi generasi mendatang, saat migas dan gas di wilayah Bojonegoro sudah habis. Adapun Target besaran Dana Abadi adalah sebesar 2025 miliar rupiah per tahun yang akan dikumpulkan dalam kurun waktu 30 tahun, di tambah 20 tahun.

Pembentukan Dana Abadi Migas ini didasarkan pertimbangan, menghindari "kutukan sumber daya alam". Berkaca dari pengalaman daerah-daerah kaya sumber daya alam, termasuk sumber daya migas, di mana justru tingkat kesejahteraan dan pembangunan manusianya lebih rendah dibanding daerah-daerah miskin sumber daya alam. Tingkat konflik sosial cukup tinggi, kerusakan lingkungan cukup parah, dutch 
desiase atau melemahnya sektor lain seperti pertanian, belanja berlebihan (over spending), korupsi tumbuh subur dan lain sebagainya (Sholikin, 2019).

Berbeda dengan Suyoto, selama kepemimpinan Anna, Bojonegoro belum memiliki peraturan baru mengenai tata kelola tambang Migas. Saat ini, kebijakankebijakan yang disahkan Anna banyak terfokus pada pembangunan infrastruktur seperti jalan, gedung dan industri (sesuai dengan visi dan misi Anna). Sedangkan persoalan lingkungan akibat aktivitas pertambangan, tampak belum serius dipertimbangkan, padahal aktifitas pertambangan dapat menimbulkan masalah lingkungan dan sosial. Salah satu contoh misalnya, pada tahun 2016 pernah ada kasus keracunan akibat pembakaran gas flare hingga menyebabkan delapan korban keracunan pada tahun (kertiyasa, 2018). Selain itu, sebanyak $64,64 \%$ petani di Bojonegoro juga menyatakan bahwa industri pertambangan berpengaruh besar terhadap berkurangnya penghasilan mereka (Rifa'i \& Mardiansjah, 2018).

Selain berkurangnya panen hasil pertanian dan suhu udara yang semakin panas. Dampak lainnya terhadap perempuan adalah maraknya kawin kontrak pada daerah eksploitasi, ini disebabkan karena banyaknya tenaga proyek dari luar daerah yang memanfaatkan momen bekerja diluar kota. Pertambangan di Bojonegoro, pada kenyataannya telah menimbulkan permasalahan sosial dan permasalahan ekologi.

Memang persoalan tambang dan dampak tambang bukan semata bersandar pada kebijakan pemerintah daerah, pemerintah pusat dalam hal ini memiliki andil terbesar dalam tata kelola tambang. Kundori, direktur Ademos mengutarakan "Pemerintah menetapkan Blok cepu di Bojonegoro ditingkatkan menjadi 220 ribu barel perhari ini merupakan kapasitas yang sudah punya, yang sebelumnya alat exxon maksimal kapasitas 160rb barel/hari". Kutipan wawancara ini menunjukkan bagaimana pemerintah pusat berupaya menggenjot penerimaan negara dari Migas di Bojonegoro, yang berimplikasi pada eksploitasi SDA secara besar-besaran.

Perusahaan tambang sendiri, memiliki kewajiban untuk mengalokasikan sebagian dana perusahaan untuk mendanai Corporate Social Responsibility (CSR). Berdasarkan dokumen Rencana Pembangunan Jangka Menengah Daerah (RPJMD) Bojonegoro Tahun 2018 - 2023, tampak bahwa realisasi kegiatan CSR di Bojonegoro tahun 2018 mencapai sebesar Rp. 28.6607.896.250,- . (Bojonegoro, 2018) Dari nominal tersebut, perusahaan dengan kontribusi CSR terbesar adalah ExxonMobil dengan total dana sebesar Rp. 20.500.000.000,-. Sisa dari nominal tersebut kemudian diisi dana CSR dari Pertamina, PD Pasar, Bank Jatim, Bank Panin, Aston Hotel, Fave Hotel dan Griya MCM.

Dalam praktiknya, dana CSR diserahkan pengelolaannya dengan menggandeng sejumlah NGO. Beberapa NGO yang memiliki akses pengelolaan terhadap program CSR oleh perusahaan Migas di Bojonegoro memiliki program seperti peningkatan ekonomi 
masyarakat, perawatan lingkungan, hingga pemberdayaan perempuan. Sebagai perusahaan tambang, Exxon dan Pertamina melaksanakan tanggungjawab CSR dengan baik, bahkan jumlah dana CSR yang mereka gelontorkan setiap tahunnya semakin besar. Pada tahun 2020 ini, total dana yang mereka keluarkan adalah sekitar 34,5 Milyar yang dibagi menjadi dua bagian yaitu $60 \%$ masuk ke wilayah terdampak tambang, dan $40 \%$ ke wilayah luar tambang. Dalam pengelolaan dana tersebut, pemerintah Bojonegoro selaku aktor pemerintah mengeluarkan kebijakan terkait presentase pembagian dana CSR. Pembagian yang awalnya $100 \%$ diberikan kepada wilayah yang terdampak tambang, dibagi menjadi $60-40$. Kebijakan ini diambil untuk pemerataan dana CSR, sebagai upaya pembangunan di seluruh wilayah Bojonegoro.

Salah satu NGO yang masuk sebagai pengelola dana CSR tambang, misalnya adalah Ademos (Asosiasi Untuk Demokrasi dan Kesejahteraan Sosial). Ademos menerima dana sekitar 1 Milyar sebagai mitra Exxon Mobil dalam rangka memberikan pertanggungjawabannya kepada alam dan masyarakat. Program kerja ademos, fokus pada pemberdayaan ekonomi masyarakat melalui penanaman bibit sayuran. Hal ini diinisiasi karena lingkungan wilayah sekitar mata pencahariannya semakin menghilang karena tanah yang biasa mereka tanami mulai dibeli untuk proses eksploitasi. Pengelolaan yang terfokus pada peningkatan kesejahteraan ini seolah-oleh menidurkan gerakan-gerakan lingkungan.

Kehadiran NGO telah memberikan warna baru terhadap gerakan sosial di Bojonegoro, terutama NGO yang memiliki keterikatan terhadap dana dari ExxonMobil dan Pertamina. Isu pembangunan merupakan fokus dari gerakan LSM semacam ini, dan tampak sebagai kelompok developmentalis oriented yang memanfaatkan isu pembangunan. Komodifikasi kemiskinan dan isu pembangunan dilakukan oleh NGO, praktik-praktik ini menggejala di Bojonegoro.

Vandana Shiva menyebutkan bahwa bendungan, tambang, bangunan-bangunan kokoh, markas militer merupakan sebuah markas pemujaan yang dinamakan pembangunan. Apa yang dikorbankan dalam suatu pembangunan, adalah perampasan hak-hak atas pengelolaan tanah, sehingga memunculkan adanya konflik dan gerakan revolusioner dalam rangka menentang eksploitasi alam yang sangat besar (Shiva, V., \& Mies, 2005). Kenyataannya di wilayah Bojonegoro tidak ditemukan adanya sebuah gerakan dalam menentang adanya tambang, terutama yang dilakukan oleh perempuan. Masyarakat termasuk kelompok perempuan relatif menikmati "pemberdayaan" yang dilakukan oleh CSR ketimbang memberikan warna baru melalui pergerakannya sendiri.

Dalam perspektif modernisasi, pembangunan bertujuan menciptakan kesejahteraan dan kemakmuran bagi seluruh masyarakat. Namun, yang terjadi justru menyebabkan adanya degradasi lingkungan dan kemiskinan yang berkepanjangan. Jebakan kemiskinan dihasilkan melalui hutang dalam konteks pembangunan, kerusakan 
lingkungan dan program penyesuaian struktural dengan kelompok yang paling menanggung beban adalah perempuan dan anak-anak.

Pengelolaan tambang modern, umumnya dilakukan dengan mengandalkan teknologi dan alat berat. Dalam hal ini Herman Daly menuturkan, bahwa teknologi merupakan bagian dari solusi dan bukan dari masalah adalah sesuatu yang mustahil (Magdoff \& Foster, 2018). Pembangunan dengan perspektif anthroposentrisme yang mengeksploitasi SDA, merupakan awal penyebab adanya degradasi lingkungan. Sehingga dana CSR, sebenarnya bukan satu-satunya jalan untuk mengatasi masalah tersebut. Pelaksanaan CSR serta kebijakan Pemerintah Bojonegoro tentang distribusi dana CSR tidak menyelesaikan pangkal permasalahan sosial dan lingkungan. Munculnya blok-blok pertambangan baru seperti Blok Cepu Lapangan Jambaran-Tiung Biru dan Blok Nona menunjukkan kerakusan manusia dalam mengeksploitasi SDA. Dalam rangka mengatasi atau meminimalisir kerusakan lingkungan, dapat saja Pemerintah Bojonegoro mengajukan moratorium pembukaan blok baru kepada pemerintah pusat.

\section{Penutup}

Transisi kepemimpinan Bupati Bojonegoro dari Suyoto ke Anna Mu'awanah, belum menunjukkan adanya perubahan kebijakan yang signifikan menyasar pada isu gender maupun tata kelola tambang. Selama kepemimpinan Anna memang ada beberapa kebijakan yang mempertimbangkan perempuan seperti moden perempuan dan pembentukan Satgas PPA, namun kebijakan-kebijakan tersebut tampak lebih memasukkan kebutuhan gender praktis dibandingkan kebutuhan gender strategis, karena belum ditujukan untuk mengubah relasi yang asimetris di antara laki-laki dengan perempuan.

Perbedaan antara kepemimpinan Suyoto dan Anna, bahhwa dalam rentang waktu satu tahun minimal Suyoto telah menghasilkan kebijakan terkait perempuan atau lingkungan sebanyak satu peraturan bupati, sedangkan Anna sama sekali belum mengeluarkan peraturan terkait perempuan ataupun lingkungan, sebaliknya Anna menghapus peraturan terkait Kesehatan.

Meski dalam aspek struktur pemerintahan, kepemimpinan Anna menunjukkan upaya-upaya mempromosikan perempuan melalui penunjukan perempuan sebagai pimpinan dinas/badan. Tetapi kebijakan Anna, tampak lebih fokus pada pembangunan fisik dan ekonomi sehingga justru berlawanan dengan perspektif feminisme. Saat ini, kebijakan-kebijakan yang disahkan Anna banyak terfokus pada pembangunan infrastruktur seperti jalan, gedung dan industri (sesuai dengan visi dan misi Anna).

Pembangunan yang dilakukan semata-mata karena pertimbangan ekonomi, biasanya berakibat pada kerusakan lingkungan dengan kelompok terdampak utamanya adalah perempuan. Maka dalam konsep keterwakilan, kepemimpinan Anna dapat 
R. Famelasari \& J. H. Prastiwi Kepemimpinan Perempuan dan Tata Kelola Tambang di Bojonegoro

dikategorikan sebagai kepemimpinan formalistik dan simbolik. Kesimpulan tersebut didapatkan dari fakta bahwa setelah dua tahun sejak dilantik pada 2018, terpilihnya Anna sebagai bupati belum menghasilkan produk peraturan daerah yang mengatur tata kelola tambang ataupun mengatur isu kesehatan yang dominan sebagai permasalahan perempuan di Bojonegoro.

\section{Ucapan Terima Kasih}

Kami mengucapkan terima kasih kepada para narasumber yang berkenan menjadi informan penelitian ini dan pihak-pihak yang membantu dalam proses pencarian data dan observasi lapangan.

\section{Pendanaan}

Penulisan jurnal ini dilakukan atas pembiayaan penelitian dari Dana PNBP, Fakultas IImu Sosial dan Ilmu Politik, Universitas Brawijaya tahun 2020.

\section{Daftar Pustaka}

Adair, J. (2008). Kepemimpinan yang Memotivasi. 2008: PT Gramedia Pustaka Utama.

Anshor, M. U. (2008). Tantangan Kepemimpinan Perempuan di Tingkat Lokal. Yinyang: Jurnal Studi Islam Gender Dan Anak, 3(1), 81-88.

Asyari, Y. (2018). Rekapitulasi Selesai, Paslon Anna - Wawan Menang Telak. Retrieved from https://www.jawapos.com/jpgtoday/06/07/2018/rekapitulasi-selesaipaslon-anna-wawan-menang-telak/

Atnike Nova, S. (2019). Memperkuat Representasi Substantif Perempuan Melalui Model Keterlibatan Gerakan Perempuan Dengan DPR dan DPRD di Indonesia. Jurnal Perempuan, 24(2), 115-123.

Bojonegoro, P. (2014). Migas. Retrieved from http://www.bojonegorokab.go.id/menu/ index/Migas

Bojonegoro, P. (2019a). Bojonegoro Dalam angka tahun 2019. Bojonegoro: Pemkab Bojonegoro.

Bojonegoro, P. (2019b). Profil Kesehatan Bojonegoro. Bojonegoro: Dinkes Bojonegoro.

Bojonegoro, P. (2020). . Ringkasan Rancangan Perubahan Anggaran Pendapatan Dan Belanja Daerah Tahun 2020.

BPS. (2019). Jumlah Penduduk Miskin menurut Kabupaten/Kota di Jawa Timur (Ribu Jiwa), 2017-2019. Retrieved from https://jatim.bps.go.id/: https://jatim.bps.go.id/indicator/23/421/1/jumlah-penduduk-miskin-menurutkabupaten-kota-di-jawa-timur.html

Childs, Sarah, \& Lovenduski, J. (2012). Political Representation. In Oxford Handbook of Gender and Politics. Oxford: Oxford: Oxford University Press. 
Dewi, M. A. (2001). Dimensi Politik Gerakan Perempuan: Suatu Survey. Jurnal Ilmu Sosial Dan IImu Politik, 5(1), 1-21.

Dinas Kesehatan Jatim. (2018) Profil Kesehatan Provinsi Jawa Timur Tahun 2018. Dinas Kesehatan Provinsi Jawa Timur. Diakses dari: https://dinkes.jatimprov.go.id/ userfile/dokumen/BUKU\%20PROFIL\%20KESEHATAN\%20JATIM\%202018.pdf

Idris, N. (2010). Fenomena, Feminisme dan Political Self Selection Bagi Perempuan. Wacana Journal of Social and Humanity Studies, 13(1), 116-131.

Lumban Gaol, A. M. (2019). Dua Dekade Demokrasi Indonesia dan Meredupnya Agenda Feminis.

Magdoff, F., \& Foster, J. B. (2018). Lingkungan Hidup dan Kapitalisme. Marjin Kiri.

Merdeka. (2018). Profil Anna Muawanah.

NDI. (2016). Why Women in Politics.

Nugroho. (2020). TII: Pemerintahan Bupati Anna Alami Kemunduran Keterbukaan Informasi. Retrieved from https://suarabanyuurip.com/kabar/baca/tii-pemerintahan-bupati-anna-alami-kemunduran-keterbukaan-informasi

Nuryati. (2015). Feminisme dalam Kepemimpinan. Jurnal Istinbath, 16, 161-179.

Pratiwi, A. M. (2019). The Policies, Practices, and Politics of Women Representation in Political Parties: A Case Study of Women Members of Parliament in Regency/Citylevel Legislative Council Period 2014-2019. Jurnal Perempuan, 24(2), 151-163.

Rifa'i, A. B., \& Mardiansjah, F. H. (2018). Dampak Perubahan Penggunaan Lahan Pertanian Terhadap Sosial Ekonomi Petani Sekitar Lokasi Pertambangan Banyu Urip Kecamatan Gayam Kabupaten Bojonegoro. Jurnal Tata Loka, 20(1), 55.

Safuan, M. (2019). DLH Jatim: Dampak Pertambangan Sumur Tua Kedewan Memprihatinkan. Retrieved from http://blokbojonegoro.com/2019/09/25/dlhjatim-dampak-pertambangan-sumur-tua-kedewan-memprihatinkan/

Shiva, V., \& Mies, M. (2005). Ecofeminismee Perspektif Perempuan Dan Lingkungan. Jogjakarta: Ire Press.

Shiva, V. (1997). Bebas dari Pembangunan: Perempuan, Ekologi dan Perjuangan Hidup di India. Jakarta: Yayasan Obor Indonesia.

Sholikin, A. (2019). Petroleum Fund pada Pemerintahan Lokal (Studi Kasus Inovasi Kebijakan "Dana Abadi Migas" Di Bojonegoro). Jurnal Ilmu Administrasi: Media Pengembangan Ilmu Dan Praktek Administrasi, 16(1), 127-146.

Siddiqoh, E. A. A. (2015). Konflik Masyarakat Penambang Minyak Mentah (Analisis Konflik Pengelolaan Pertambangan Minyak Mentah Desa Wonocolo, Kecamatan Kedewan, Kabupaten Bojonegoro Periode 2009-2015). UNIVERSITAS AIRLANGGA.

Zega, Christiani, D., \& Saraswati, P. (2014). Relasi Alam dan Perempuan dalam Pemikiran Ekofeminisme Vandana Shiva. Depok: UI: Program Studi Ilmu Filsafat. 
R. Famelasari \& J. H. Prastiwi Kepemimpinan Perempuan dan Tata Kelola Tambang di Bojonegoro

\section{Daftar Narasumber}

Mitroatin, DPRD Bojonegoro Fraksi Golkar, 12 Juli 2020, Pukul 10.00 WIB.

Himmah, Ketua Koalisi Perempuan Indonesia Cabang, 12 Juli 2020, Pukul 13.10 WIB.

Kundori, Direktur Ademos, 13 Juli 2020, Tambang Bojonegoro Pukul 11.45 WIB.

Rori, Sekretaris Cabang PDIP Bojonegoro, 13 Juli 2020, Tambang Bojonegoro Pukul 14.00 WIB.

Miftah, Ketua Forum Indonesia Untuk Transparansi Anggaran,s 13 Juli 2020, Tambang Bojonegoro. Pukul 16.00 WIB.

\section{Tentang Penulis}

Resya Famelasari adalah Dosen IImu Politik, Fakultas IImu Sosisal dan IImu Politik Universitas Brawijaya Malang. Penulis memiliki area riset seputar tema kebijakan publik.

Juwita Hayyuning Prastiwi adalah Dosen IImu Politik, Fakultas IImu Sosisal dan IImu Politik Universitas Brawijaya Malang. Penulis memiliki area riset seputar tema politik dan gender. 